\title{
Prostaglandin Production and Zinc Depletion in Human Pregnancy
}

\author{
KAREN SIMMER, NEVILLE A. PUNCHARD, GERRY MURPHY, AND \\ RICHARD P. H. THOMPSON \\ Gastrointestinal Laboratory [K.S., N.A.P., R.P.H.T.], Rayne Institute, St. Thomas' Hospital, and Department of \\ Biochemistry [G.M.], Guy's Hospital Medical School, London, England
}

\begin{abstract}
An association between zinc depletion and intrauterine growth retardation might occur through disturbed prostaglandin (PG) synthesis. The zinc content and PG metabolism of leucocytes from control, nonpregnant women and mothers $24-48 \mathrm{~h}$ after delivery, were measured and related to fetal growth and maternal smoking. Mothers of small for gestational age babies had lower polymorphonuclear and mononuclear cell zinc contents than mothers of appropriate for gestational age babies or nonpregnant controls. Monocytes were the major leucocytes producing PGs. Mothers of small for gestational age babies had higher $\mathrm{PGE}_{2}: \mathrm{F}_{2 \alpha}$ ratios than mothers of appropriate for gestational age babies. $\mathbf{P G F}_{2 \alpha}$ production and $\mathbf{P G E}_{2}: \mathbf{F}_{2 \alpha}$ ratio were correlated with tissue zinc status. Monocytes from nonsmokers tended to produce more PGs than those from smokers but the differences were not significant. Mild maternal zinc depletion is not significantly sufficient to alter absolute PG production, but is associated with altered differential production of PGs in human leucocytes. Zinc depletion or malnutrition may contribute to intrauterine growth retardation by affecting placental and/or umbilical PG production. (Pediatr Res 19: 697-700, 1985)
\end{abstract}

\section{Abbreviations}

PG, prostaglandin

SGA, small for gestational age

AGA, appropriate for gestational age

IUGR, intrauterine growth retardation

PMN, polymorphonuclear

MN, mononuclear

MC, monocyte

IUGR is an important cause of perinatal morbidity and mortality in developed, as well as developing, countries, and in both animals $(1,2)$ and man $(3,4)$ occurs with maternal zinc depletion. Zinc is present in many metalloenzymes and is essential for DNA and RNA synthesis and, therefore, protein accumulation and growth (5). It is also important in the structure and function of biomembranes (6). An interaction between zinc and essential fatty acids has been postulated $(7,8)$, but aberrations in the metabolism of essential fatty acids attributed to zinc deficiency may be due to the accompanying reduced food intake (9). Zinc may be necessary for at least two stages in essential fatty acid

Received December 4, 1984; accepted March 5, 1985.

Correspondence to Dr. Karen Simmer, Gastrointestinal Laboratory, Rayne Institute, St. Thomas' Hospital, London SE1 7EH, London.

Supported by Action Research, Nestle Nutrition Foundation, and the Special Trustees of St. Thomas' Hospital. metabolism, namely the conversion of linoleic acid to $\gamma$-linolenic acid, and the mobilization of dihommogammalinolenic acid for the synthesis of 1 series PGs. Zinc may also be important in the conversion of dihommogammalinolenic acid to arachidonic acid and for mobilization of arachidonic acid for 2 series PG formation (10). One of the immediate consequences of zinc depletion may be altered PG metabolism and, as PGs are important in placental function and fetal growth (11), an association between zinc depletion and IUGR might occur through disturbed PG synthesis.

Leucocytes are readily available and produce prostaglandins (12). Their zinc content is a good indicator of zinc status (13) and they extensively penetrate the placenta (14). We have investigated the relationship between PG production and zinc depletion in human pregnancy by studying the zinc content and PG metabolism of leucocytes, and relating these to fetal growth and maternal smoking.

\section{PATIENTS AND METHODS}

Seventeen mothers were studied 24-48 $\mathrm{h}$ after delivery and values compared to those in 17 control, nonpregnant women. The mothers were divided into two groups: group I $(n=11)$ delivered babies of normal birth weight or AGA, and group II ( $n$ $=6$ ) delivered SGA babies. Babies were defined as SGA if their birth weight was less than the 10th percentile, corrected for gestational age, sex, race, and maternal height. Group I had a mean age of $27 \mathrm{yr}$ (range 17-34 yr), group II 23 yr (range 19-36 $\mathrm{yr}$ ), and the control group, $27 \mathrm{yr}$ (range 22-29 yr). Mothers of small but AGA, namely preterm, babies were not studied.

Preparation of $P M N$ and $M C$ cell populations. Peripheral venous blood was collected at $0900 \mathrm{~h}$ into heparin, $10 \mathrm{U} / \mathrm{ml}$ (Leo Laboratories Ltd, Bucks, England). Thirty six milliliters blood with $9 \mathrm{ml}$ dextran 150 in $0.16 \mathrm{M} \mathrm{NaCl}$ (Fisons, Loughborough, England) was sedimented for 20-30 min (15) and the supernatant layered on Ficoll-Paque (Pharmacia Fine Chemicals, Uppsala, Sweden) and centrifuged at room temperature for 20 min at $400 \times g(16)$. PMN and MN cells were separated, and contaminating red blood cells were removed by hypotonic lysis. The cells were resuspended in phosphate buffer solution.

Cell counts and assessment of population purity were performed manually, using a Neubauer haemocytometer chamber after methylene blue staining. Purities were greater than $90 \%$ for PMN cells and $80 \%$ for MN cells. The percentage composition of the MN population was assessed by staining for nonspecific esterases $(17,18)$. Viability was established by vital dye exclusion, using $15 \%$ trypan blue in $0.15 \mathrm{M}$ saline (19), and was always greater than $95 \%$.

To determine which subpopulation of MN cells was producing the majority of PGs, the MN cell suspensions from three additional mothers were depleted of MCs by glass adherence. The 
concentration of lymphocytes was maintained and incubations were performed in parallel with the original MN cells.

Cell incubations. Cell incubations were performed in duplicate at $37^{\circ} \mathrm{C}$ in $2 \mathrm{ml}$ TC 199 medium (Wellcome Reagents, Beckenham, England) and $20 \mathrm{mM}$ HEPES buffer (Flow Laboratories, Rickmansworth, England), pH 7.4. Cells were incubated at a density of $10^{5}$ monocytes per milliliter and stimulated with zymosan, $50 \mu \mathrm{g} / \mathrm{ml}$ medium (Sigma Chemical Co., Dorset, England). PMN cells were also stimulated with N-formyl-L-methionyl-L-leucyl-phenylalanine, $2.5 \times 10^{-5} \mathrm{M}$ (Sigma).

Incubations were stopped by centrifugation and the supernatants stored at $-70^{\circ}$ for less than $4 \mathrm{wk}$ before analysis.

Zinc analysis. After cells had been removed for incubation, the remainder were digested for 3 days in $5-10 \mathrm{ml} 0.1 \mathrm{M}$ nitric acid and the zinc content was measured by flame atomic absorption spectrophotometry (Instrumentation Laboratory 257 Cheshire, England). Precision of the assay, assessed as within-assay and between-assay coefficient of variation, was always less than $3 \%$.

Both internal and external zinc standards (Nyegaard, Birmingham, England) were used with $98 \%$ agreement.

$P G$ analysis. Analysis of $\mathrm{PGE}_{2}$ and $\mathrm{PGF}_{2 \alpha}$ was performed in duplicate directly on the incubation media by RIA. Briefly, tracer and antisera were added to standards and samples. After incubation overnight at $4^{\circ} \mathrm{C}, 0.5 \%$ charcoal and $0.05 \%$ dextran in buffer were added for $10 \mathrm{~min}$ to remove unbound PG. Samples were centrifuged for $5 \mathrm{~min}$ at $2000 \times g$ and the supernatants counted with an LKB $\beta$ counter. The antisera and PG standards were obtained from Sigma, and ${ }^{3} \mathrm{H}-\mathrm{PGE}_{2}(5.9 \mathrm{TBq} / \mathrm{mmol})$ and ${ }^{3} \mathrm{H}-\mathrm{PGF}_{2 \alpha},(6.7 \mathrm{TBq} / \mathrm{mmol})$ from Amersham International (Bucks, England). All other reagents were from British Drug Houses (Dorset, England).

Sensitivity of each assay was $5-200 \mathrm{pg} / 100 \mu \mathrm{l}$ medium. Recovery of added PGs from the incubation media was $101 \pm 18 \%$ for $\mathrm{PGE}_{2}(n=23)$ and $101 \pm 14 \%$ for $\mathrm{PGF}_{2 \alpha}(n=21)$, mean \pm $\mathrm{SD}$. Because error is nonhomogenously distributed over a RIA standard curve (20), precision was assessed at 5-20, 20-100, $100-200 \mathrm{pg} / 100 \mu \mathrm{l}$. The within-assay coefficient of variation for $\mathrm{PGE}_{2}$ was 8.5, 8.7, and $11.5 \%$ and, for $\mathrm{PGF}_{2 \alpha}, 19.6,9.2$, and $7.1 \%$. The between-assay coefficient of variation for $\mathrm{PGE}_{2}$ was 12.7, 9.2, and $14.9 \%$ and for $\mathrm{PGF}_{2 \alpha}, 17.6,9.3$, and $13.9 \%$. Specificity was assessed by sample dilution and by cross-reactivity. Dilution of sample closely followed the standard curve $(r=$ 1.0 , gradient $=1.0$ for $\mathrm{PGE}_{2}$ and $r=1.0$, gradient $=0.97$ for $\mathrm{PGF}_{2 \alpha} ; n=21$ ). Cross-reactivities of the antisera were confirmed for $\mathrm{PGE}_{2}, \mathrm{PGF}_{2 \alpha}, 6 \mathrm{KF}_{1 \alpha}, \mathrm{PGA}_{2}, \mathrm{PGB}_{2}, 13,14$ dihydro-15-keto$\mathrm{PGF}_{2 \alpha}$, arachidonic acid, and linoleic acid. Notable cross-reactivities were noted for $\mathrm{PGF}_{2 \alpha}, 100 \%$ with $\mathrm{PGF}_{1 \alpha} \mathrm{PGE}_{2}$, and $3.2 \%$ with $\mathrm{PGE}_{1}$. All RIA calculations were performed by the logit probit analysis (21).

Subjects gave informed consent and the studies were approved by the hospital ethical and obstetric committees. The results are expressed as means \pm SEM and analysed by unpaired, bitailed Student's $t$ test, and least squares linear regression analysis.

\section{RESULTS}

Zinc analysis (Table 1). Group I mothers and controls had similar leucocyte zinc levels. Group II mothers had significantly lower PMN and MN cell zinc concentrations. PMN and MN zinc levels were weakly correlated $(r=0.4, p<0.05)$. There were no differences in the zinc contents of PMN or MN cells between smoking $(n=6)$ and nonsmoking $(n=18)$ controls and mothers: $69 \pm 8$ versus $67 \pm 5 \mu \mathrm{g} / 10^{10} \mathrm{PMN}$ and $170 \pm 29$ versus $164 \pm$ $13 \mu \mathrm{g} / 10^{10} \mathrm{MN}$, respectively.

Cell incubations. PMN leucocytes. No PG production was detected when PMN cells were incubated for $4 \mathrm{~h}$ with zymosan or N-formyl-L-methionyl-L-leucyl-L-phenylalanine $(n=10)$.

$M N$ leucocytes. The adherent populations (MC) produced the majority of PGs: $20.5 \pm 6.0$ versus $4.3 \pm 0.6 \mathrm{pg} \mathrm{PGE}_{2} / 10^{6} \mathrm{MN} /$ $2 \mathrm{~h}(n=3), p<0.05$ and $17.3 \pm 3.5$ versus $6.2 \pm 2.5 \mathrm{pg}$ PGF $_{2 \alpha} /$
Table 1. PMN and $M N$ cell zinc contents (mean $\pm S E M$ )

\begin{tabular}{cccc}
\hline & $\begin{array}{c}\text { Control } \\
(n=15)\end{array}$ & $\begin{array}{c}\text { Group I } \\
\text { mothers } \\
(n=10)\end{array}$ & $\begin{array}{c}\text { Group II } \\
\text { mothers } \\
(n=6)\end{array}$ \\
\hline$\mu \mathrm{g} \mathrm{zinc} / 10^{10} \mathrm{PMN}$ & $74 \pm 6$ & $68 \pm 5$ & $50 \pm 4^{*}$ \\
$\mu \mathrm{g} \mathrm{zinc} / 10^{10} \mathrm{MN}$ & $167 \pm 13$ & $192 \pm 20$ & $120 \pm 11 \dagger$ \\
\hline
\end{tabular}

${ }^{*} p<0.025$ II versus control, $p<0.05$ II versus I.

$\dagger p<0.05$ II versus control, $p<0.025$ II versus I.

$10^{6} \mathrm{MN} / 2 \mathrm{~h}(n=3), p<0.05$, total MN cells $\mathrm{v}$ monocytedepleted MN cells, respectively. Results are, therefore, expressed as $\mathrm{pg} / 10^{5} \mathrm{MC}$. There was a steady accumulation of $\mathrm{PGE}_{2}$ and $\mathrm{PGF}_{2 \alpha}$ from $1-4 \mathrm{~h}(r=0.9 \pm 0.06$ and $0.97 \pm 0.02$, respectively, $n=4)$. Cells were, therefore, cultured for $2 \mathrm{~h}$.

There were no significant differences in the mean $\mathrm{PGE}_{2}$ and $\mathrm{F}_{2 \alpha}$ production by $\mathrm{MC}$ cells of control women and all mothers or by MC cells of mothers of AGA and SGA babies. However, all mothers had a higher $\mathrm{E}_{2} / \mathrm{F}_{2 \alpha}$ ratio than nonpregnant controls and group II had a higher $\mathrm{PGE}_{2} / \mathrm{PGF}_{2 \alpha}$ ratio than group I mothers (Table 2). Both results were chiefly due to lower $\mathrm{PGF}_{2 \alpha}$ production by cells from group II mothers.

There were weak correlations between zinc status and $\mathrm{PGF}_{2 \alpha}$ production $(r=0.6, p<0.05)$ and $\mathrm{PGE}_{2} / \mathrm{PGF}_{2 \alpha}$ ratio $(r=-0.7$, $p<0.01$ ) in pregnancy, $n=15$ (Fig. 1 ).

Mothers and controls were combined and the effect of smoking on PG production was analyzed. There was a tendency for monocytes from nonsmokers to produce more PGs than those from smokers, but the differences were not significant (162 \pm 23, $n=19$ versus $96 \pm 26, n=7 \mathrm{pg} \mathrm{PGE} / 10^{5} \mathrm{MC} / 2 \mathrm{~h}$ and 175 $\pm 30, n=19$ versus $100 \pm 32, n=7 \mathrm{pg} \mathrm{PGF}_{2 \alpha} / 10^{5} \mathrm{MC} / 2 \mathrm{~h}$, nonsmokers versus smokers).

\section{DISCUSSION}

PMN cell zinc content is a simple and reliable indicator of tissue zinc status and its measurement requires less blood and is more reproducible than $\mathrm{MN}$ cell zinc. Maternal zinc depletion is associated with IUGR and this is confirmed in our recent larger study of 80 mothers, in which zinc depletion was also associated with smoking (22). In addition to tissue zinc depletion, decreased umbilical arterial production of prostacyclin, measured as its stable product, 6-keto $F_{1 \alpha}$, is also associated with IUGR (23) and smoking (24), while umbilical prostacyclin production parallels umbilical blood flow (25). Variations of umbilical blood flow might be an important factor controlling fetal size.

The measurement by RIA of PG production in vitro has advantages over using the radiolabeled precursor, arachidonic acid, for exogenous arachidonic acid is used by cells differently from the endogenous molecule (12), and it may not follow the endogenous substrate present or equilibrate with the same pool as that used for PG synthesis. Measuring the extra PG synthesized in response to a specific stimulus overcomes the problem of PGs being released by nonspecific stimuli during the preparation of cells.

Monocytes were the major leucocytes producing PGs, confirming previous work (26). Significant differences in the absolute leucocyte PG production were not detected between controls and mothers of AGA and SGA babies, despite the latter group being zinc depleted and there being a weak correlation between PG production and PMN zinc status. However, group II mothers did have an increased $\mathrm{PGE}_{2} / \mathrm{PGF}_{2 \alpha}$ ratio, mainly due to a trend to lower $\mathrm{PGF}_{2 \alpha}$ production, indicating that $\mathrm{PG}$ production may be abnormal in mothers of SGA babies, possibly causing reduced placental perfusion.

Published results from studies with rats are conflicting. Zinc deficiency increased synthesis of PG by the placenta but not by the uterus (27) or kidney (28). Mydani and Dupont (29) found that in most organs studied and for most PGs measured, food 
Table 2. $M C P G$ production (mean $\pm S E M$ )

\begin{tabular}{|c|c|c|c|c|}
\hline & $\begin{array}{l}\text { Group I } \\
\text { mothers } \\
(n=11)\end{array}$ & $\begin{array}{c}\text { Group II } \\
\text { mothers } \\
(n=5)\end{array}$ & $\begin{array}{c}\text { All } \\
\text { mothers } \\
(n=16)\end{array}$ & $\begin{array}{l}\text { Controls } \\
(n=17)\end{array}$ \\
\hline $\mathrm{pg} \mathrm{PGE}_{2} / 10^{5} \mathrm{MC} / 2 \mathrm{~h}$ & $154 \pm 15$ & $153 \pm 38$ & $153 \pm 15$ & $142 \pm 26$ \\
\hline pg $\mathrm{PGF}_{2 \alpha} / 10^{5} \mathrm{MC} / 2 \mathrm{~h}$ & $157 \pm 22$ & $111 \pm 31$ & $142 \pm 18$ & $168 \pm 35$ \\
\hline $\mathrm{PGE}_{2}: \mathrm{PGF}_{2 \alpha}$ & $1.07 \pm 0.08^{*}$ & $1.45 \pm 0.08$ & $1.19 \pm 0.08 \dagger$ & $0.87 \pm 0.11$ \\
\hline
\end{tabular}

* $p<0.05$ mothers of AGA babies versus mothers of SGA babies. $\dagger p<0.025$ all mothes versus controls.

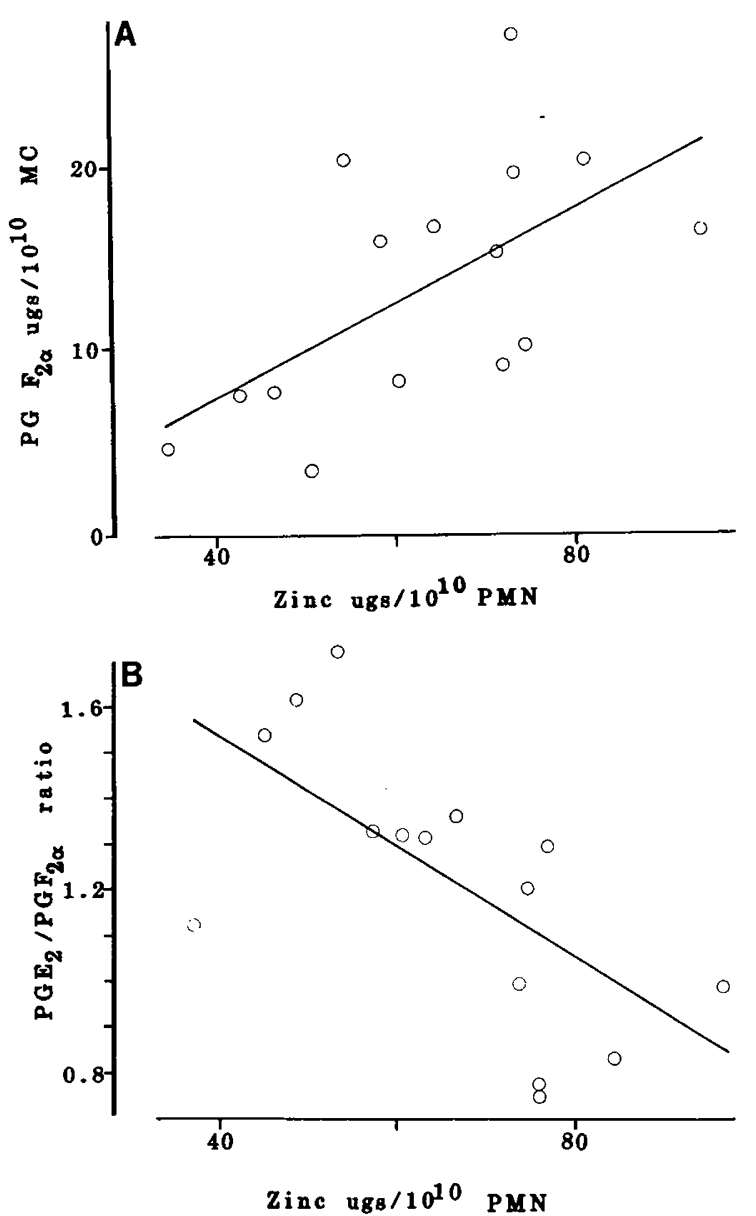

Fig. 1. $A$ and $B$, correlations between tissue zinc status (PMN cell zinc) and leucocyte $P G$ production.

restriction was as efficient as zinc deficiency in reducing PG. However, zinc deficiency increased the level of 13, 14-dihydro15-keto $\mathrm{PGF}_{2}$ in serum and reduced the concentration of $\mathrm{PGE}_{2}$ $\mathrm{PGF}_{2 \alpha}$ and 6 keto $\mathrm{PGF}_{1}$ in gut contents (where $\mathrm{PGE}_{1}$ and zinc were correlated). Kramer et al. (9) demonstrated that the phospholipids in the liver of both zinc-deficient and pair-fed control rats were similar, with increased products of $\triangle^{6}$ and $\Delta^{9}$ desaturase and decreased products of $\Delta^{5}$ and $\Delta^{4}$ desaturase. In laboratory rats the influence of reduced food intake, which accompanies zinc depletion, on the metabolism of linoleic acid to arachidonic acid may, therefore, be at least equal to that of zinc deficiency, and so without pair-fed controls the interpretation of results showing alteration in PG metabolism in zinc deficiency may have to be revised.

At present, therefore, we conclude that maternal zinc depletion, which is mild compared with severe experimental zinc deficiency, is not significantly sufficient to alter absolute PG production, but is associated with altered differential production of PGs by human leucocytes. More work, however, is needed to determine whether zinc status or malnutrition is related to placental and umbilical PG production, and thus to IUGR.

\section{REFERENCES}

1. Golib MS, Gershwin ME, Hurley LS, Baly DL, Hendrickx AG 1984 Studies of marginal zinc deprivation in rhesus monkeys. I. Influence on pregnant dams. Am J Clin Nutr 39:265-280

2. Golib MS, Gershwin ME, Hurley LS, Baly DL, Hendrickx AG 1984 Studies of marginal zinc deprivation in rhesus monkeys. II. Pregnancy outcome. Am J Clin Nutr 39:879-887

3. Jameson S 1976 Effects of zinc deficiency in human reproduction. Acta Med Scand 197(suppl 593):3-89

4. Meadows NJ, Ruse W, Smith M, Keeling PWN, Bloxam D, Day J Scopes JW, Thompson RPH 1981 Zinc and small babies. Lancet 2:1135-1137

5. Chester JK 1982 Metabolism and biochemistry of zinc. In: Prasad AS (ed). Clinical, Biochemical and Nutritional Aspects of Trace Elements, Alan R Liss, Inc, New York, pp 221-238

6. Bettger WJ, O'Dell BL 1981 A critical physiological role of zinc in the structure and function of biomembranes. Life Sci 28:1425-1438

7. Bettger WJ, Reaves PG, Moscatelli EA, Reynold G, O'Dell BL 1979 Interaction of zinc and essential fatty acids in the rat. $J$ Nutr 109:480-488.

8. Clejan S, Castro-Magana M, Collip P, Jonas E, Maddaiah VT 1982 Effects of zinc deficiency and castration on fatty acid composition and desaturation in rats. Lipids 17:129-135

9. Kramer TR, Briske-Anderson M, Johnson SB, Holman RT 1984 Influence of reduced food intake on polyunsaturated fatty acid metabolism in zinc deficient rats. J Nutr 114:1224-1230

10. Horrobin DF, Cunnane SC 1980 Interactions between zinc, essential fatty acids, prostaglandins: relevance to acrodermatitis enteropathica, total parenteral nutrition, the glucagonoma syndrome, diabetes, anorexia nervosa and sickle cell anaemia. Med Hypothesis 6:277-296

11. Challis JRG, Patrick JE 1980 The production of prostaglandins and thromboxanes in the feto-placental unit and their effect on the developing fetus. Semin Perinatol 4:23-33

12. Johnson S, Olding LB, Green K 1983 Conversion of arachidonic acid in human maternal and neonatal leucocytes. Immunol Lett 6:213-218

13. Jones RB, Keeling PWN, Hilton PJ, Thompson RPH 1981 The relationship between leucocyte and muscle zinc in health and disease. Clin Sci 60:237239

14. Wood GW 1980 Mononuclear phagocytes in the human placenta. Placenta $1: 113-123$

15. Baron DN, Ahmed SA 1969 Intracellular concentrations of water and of the principle electrolytes determined by analysis of human leucocytes. Clin Sci 37:205-219

16. Boyum A 1968 Separation of lymphocytes and erythrocytes by centrifugation. Scand J Clin Lab Invest 20(suppl 97):9-108

17. Tucker SB, Pierre RV, Jordan RE 1977 Rapid identification of monocytes in a mixed mononuclear cell preparation. J Immunol Meth 14:267-269

18. Yam LT, Lin CY, Crosby WH 1971 Cytochemical identification of monocytes and granulocytes. Am J Clin Pathol 55:283-290

19. Boyse EA, Old LJ, Chouroulmlkou I 1964 Methods in medical research. In: Eisen HN (ed) Vol 10. Chicago Year Book Medical Publishers, Chicago

20. Rodbard D, Rayford PL, Cooper JA Ross GT 1968 Statistical quality control of radioimmunassays. J Clin Endocrinol 28:1412-1418

21. Rodbard D, Bridson W, Rayford PL 1969 Rapid calculation of radioimmunoassay results. J Lab Clin Med 74:770-781

22. Simmer K, Thompson RPH 1985 Maternal zinc depletion and intrauterine growth retardation. Clin Sci 68:395-399

23. Stuart MJ, Clark DA, Sunderj SG, Allen JB, Yambo T, Elrad H, Slott JH 1981 Decreased prostacyclin production: a characteristic of placental insufficiency syndrome. Lancet 1126-1128

24. Busacca M, Dejana E, Balioni G, Olivieri S, Pietra A, Vergara-Danden M, deGaetano C 1982. Reduced prostacyclin production by cultured endothelial cells from umbilical arteries of babies born to women who smoke. Lancet 2:609-610

25. Makila V, Jonppila P, Kirkinen P, Viinikka L, Ylikrkala O 1983 Relation between umbilical prostacyclin production and blood flow in the fetus. Lancet 1:728-729

26. Morley J, Bray MA, Jones RW, Nugteren DH, Van Dorp DA 1979 Prostaglandin and thromboxane production by human and guinea pig macrophages and leucocytes. Prostaglandins 5:730-736

27. Cunnane SL, Magid E, Senior J, Mills CF 1983 Uteroplacental dysfunction 
and prostaglandin metabolism in zinc deficient pregnant rats. Life Sci $32: 2471-2478$

28. Everett $G$, Apger $J 1983$ Effect of zinc deficiency on prostaglandin $F_{2 \alpha}$ and $E$ in the rat. In: Bratter P, Schramel P (eds). Trace Elements-Analytic Chem- istry in Medicine and Biochemistry, Vol 2. Walter de Gruyter, NY, pp 219-226

29. Meydani SN, Dupont J 1982 Effect of zinc deficiency on prostaglandin synthesis in different organs of rat. J Nutr 6:1098-1104

\title{
Transfer and Metabolism of Carnitine and Carnitine Esters in the in Vitro Perfused Human Placenta
}

\author{
EBERHARD SCHMIDT-SOMMERFELD, DUNA PENN, RAVI J. SODHA, MARIETTE PRÖGLER, \\ MILAN NOVAK, AND HENNING SCHNEIDER \\ Department of Pediatrics, University of Giessen, Federal Republic of Germany; Division of Perinatal Physiology, \\ Department of Obstetrics, University of Zürich, Switzerland; and Department of Pediatrics, University of
} Miami, Florida

\begin{abstract}
The transfer and metabolism of L-carnitine, L-acetylcarnitine, and L-palmitoylcarnitine were studied in the human placenta at term by means of in vitro dual perfusion of a placental lobe. $\mathrm{x}$-Carnitine transfer was $20 \%$ that of the freely diffusing antipyrine and $40 \%$ that of $\mathrm{L}$ lysine. The transfer of $\mathrm{L}$-acetylcarnitine was similar to that of $L$-carnitine, but no placental transfer of $L$-palmitoylcarnitine was found. In contrast to L-lysine, L-carnitine, and L-acetylcarnitine were not actively transported from the maternal to the fetal circulation. No stereospecific transfer of carnitine across the placenta was found. However, there was stereospecific uptake of carnitine by placental tissue. The placenta exhibited an active carnitine metabolism by esterifying free carnitine and hydrolyzing carnitine esters taken up from the perfusion medium and releasing the metabolites into the fetal and maternal circulations. (Pediatr Res 19: 700-706, 1985)
\end{abstract}

Carnitine plays an important role in fat catabolism by facilitating the transport of fatty acids across the mitochondrial membrane (1). Its availability seems to be essential during the immediate postnatal period when fat constitutes the major source of energy $(2,3)$. Decreased carnitine blood (4-6), tissue (7), and urine (5) concentrations in premature infants receiving carnitinefree parenteral nutrition provide indirect evidence that the fetus may not be capable of substantial carnitine synthesis. This is also suggested by the low activity of the key enzyme for carnitine biosynthesis during early human development (8).

Little is known about carnitine transfer across the placenta. Large species differences have been reported. Whereas an ex-

Received April 26, 1984; accepted March 6, 1985

Reprint requests E. Schmidt-Sommerfeld, M.D. Zentrum für Kinderheilkunde, Justus-Liebig-Universität, Feulgenstr. 12, 6300 Giessen, F.R.G.

Supported by funds from the Deutsche Forschungsgemeinschaft and the Schweizer Nationalfond.

This paper is dedicated to Professor Helmut Wolf on the occasion of his 60th birthday. tremely slow carnitine placental transport has been found in the sheep in vivo, rapid transfer occurs across the guinea pig placenta (9). Until now, only indirect evidence exists for carnitine placental transfer in the human. A strong correlation has been found between maternal and umbilical carnitine blood concentrations (10). Nothing is known about the mechanism by which carnitine may cross the placenta. Free carnitine concentrations have been reported to be higher in umbilical than in maternal venous blood $(11,10)$. This finding has given rise to the speculation that active transport from the mother to the fetus occurs. However, we found decreased free carnitine and increased acylcarnitine concentrations in maternal blood at delivery compared with those from pregnant women not in labor (10). This could be attributed to acute changes in maternal fat metabolism and makes it difficult to draw conclusions about the role of the placenta in carnitine transfer from a comparison of maternal and umbilical blood levels. Moreover, carnitine acetyltransferase $(12,13)$ and carnitine palmitoyltransferase activities $(12,14)$ have been demonstrated in the human placenta suggesting that the placenta itself may actively participate in perinatal carnitine metabolism. To study human placental carnitine transfer and metabolism isolated from maternal or fetal metabolic influences, we performed experiments using the in vitro dual perfused human placental lobe.

\section{MATERIALS AND METHODS}

Perfusion technique. Twenty-seven placentas were obtained from uncomplicated term gestations by vaginal or abdominal deliveries and immediately prepared for study. Using the technique of dual perfusion of an isolated human placental lobe described by Schneider et al. (15), fine steel cannulas were inserted into the artery and vein supplying the chorionic vascular system. The lobe (mean weight $34.8 \mathrm{~g}$ ) was immediately perfused with fetal perfusate, removed from the rest of the placenta, and fixed with the maternal side upward in a thermoregulated plexiglass chamber. For establishment of the maternal circulation, three to five steel cannulas were inserted into the intervillous space by penetrating the decidual plate over the blanched area 